\title{
WHO GIVES AND WHO GETS? TAX POLICY AND THE LONG-RUN DISTRIBUTION OF PHILANTHROPY IN THE UNITED STATES
}

\author{
Nicolas J. Duquette and Jennifer Mayo
}

\section{Introduction}

It is commonly believed that giving in the United States is fairly stable. Historically, charitable contributions and philanthropic giving in the United States have remained close to 2\% of GDP (Lilly School 2020). This quantitative stability has fed a qualitative sensibility that U.S. charitable giving is a stable, entrenched, and broadly shared civic activity little affected by public policy or social changes.

This chapter provides descriptive evidence that the reality is more complicated. We describe the predictors of charitable and philanthropic donations over time from the perspective of the donors who make the contributions and the charitable organizations that receive those contributions. Over time, that $2 \%$ of GDP has come from a very different set of donors, as economic inequality and changes in social structure and demography have remade the distribution of donative behavior.

These changes are reflected in charities' receipts, as giving has shifted away from churches to secular, or at least not solely religious, organizations. By other measures, however, the concentration of public support by size, geography, and mission has been largely stable. Comparing these two pieces of evidence, we infer that while secular charities have not seen a dramatic concentration or redistribution of resources over time, many are increasingly dependent on major donors.

These trends happen in parallel with important policy changes. Over the past 70 years, federal and state tax incentives for giving have favored specific charities and specific donors, which we argue may have contributed to the trends documented here. We conclude with suggested tax reforms to expand the distribution of charitable giving among more U.S. households and a greater diversity of charities.

\section{The lopsided donation distribution}

Average charitable contributions in the United States have been remarkably stable over time. Figure 15.1 reports the mean contribution of Americans at the personal, tax unit, and household 


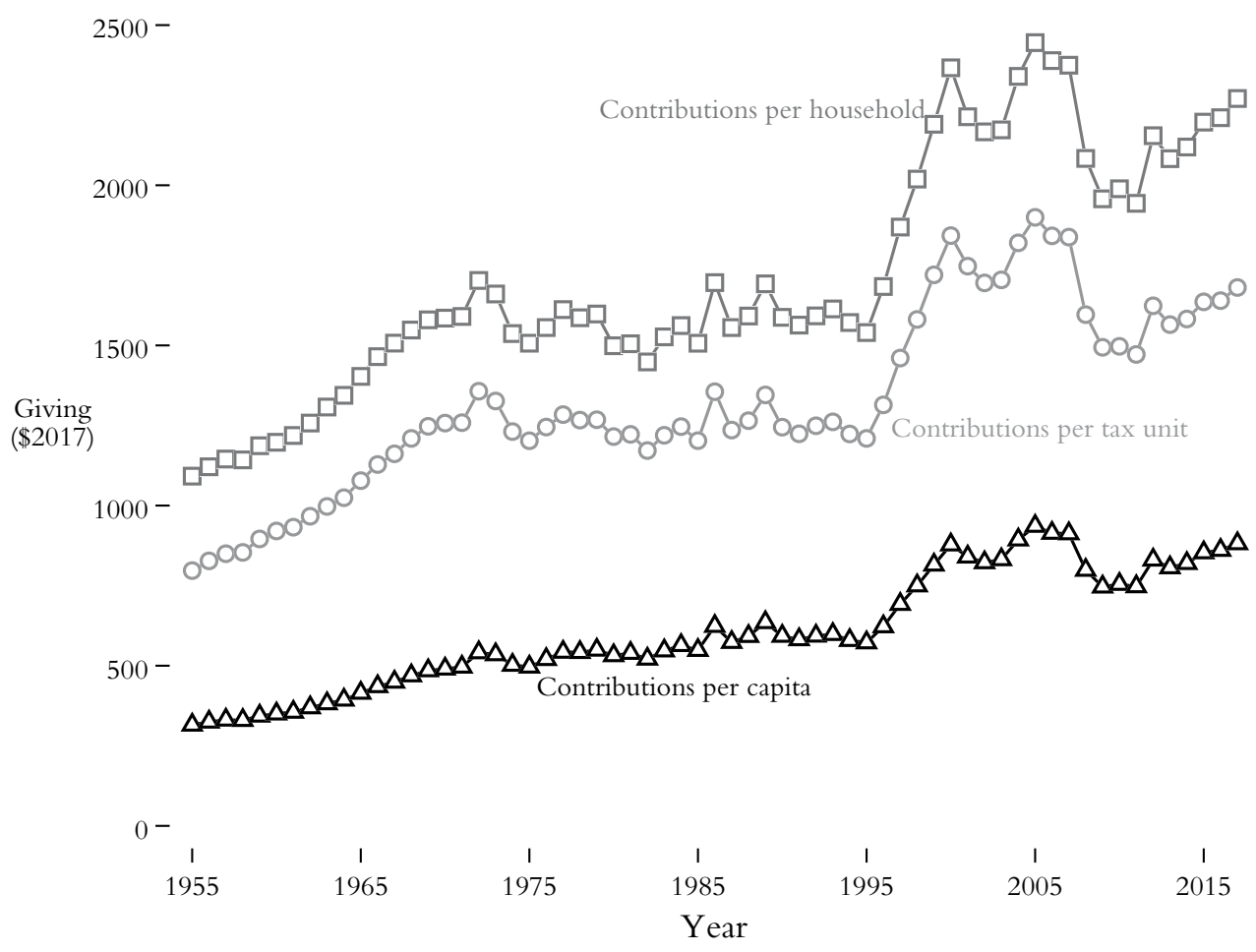

Figure 15.1 Aggregate giving in the United States

levels, calculated as Giving USA individual contributions divided by time series counts of those quantities and converted to real (2019) dollars using the Consumer Price Index. Contributions are quite stable over time, rising gradually in real terms over the very long run, with the exception of a more rapid rate of increase during the late 1990s economic boom. From these aggregates alone, it would be easy to conclude that U.S. giving is stable, predictable, and steadily increasing without cause for concern.

This apparent stability conceals important shifts in the distribution of giving activity. While scholars typically think of U.S. giving and philanthropy as a civic culture with wide participation, giving activity has become increasingly concentrated over the past 60 years. Figure 15.2 plots the share of giving by living Americans accounted for by the itemized contributions of the tax units who claim the most giving. ${ }^{1}$ These shares are computed from publicly available Internal Revenue Service (IRS) cross-sectional data for available years 1960 to 2012. ${ }^{2}$ These calculations show a rapid increase in the share of giving made by the top donors. In 1960, the top $1 \%$ of tax units made $18.9 \%$ of all charitable contributions from living individual donors. By 2012 , this share had more than doubled to $43.5 \%$.

This concentration is difficult to explain. Over this period, income has grown more concentrated, which likely accounts for a significant portion of the concentration of philanthropy. However, even the highest estimates of increased income inequality would imply a less steep increase than this rapid consolidation of giving into relatively few tax returns. It is likely that other social forces, such as the changing demography of the United States, also explain changes in who gives and how much they give. 
Donation Share

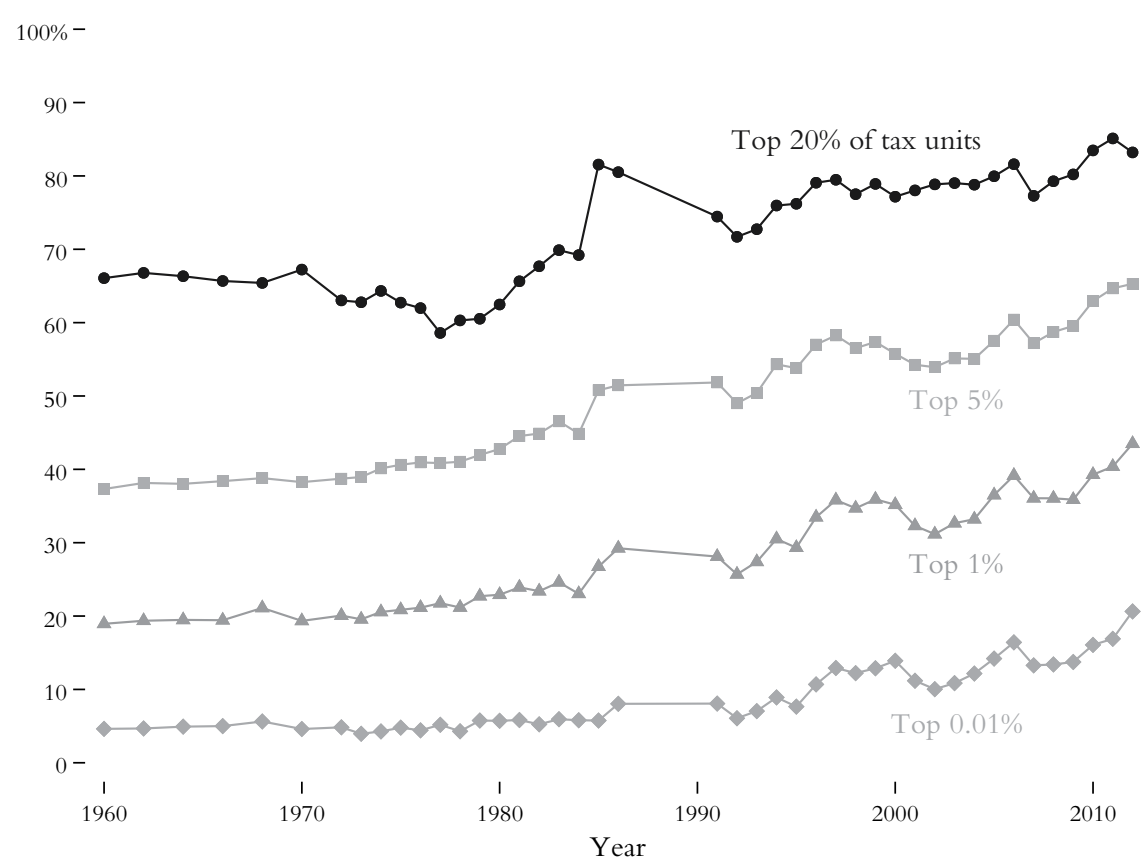

Figure 15.2 Top donors' share of annual giving

\subsection{Income inequality}

One plausible contributor to changes in the distribution of giving might be greater concentration of incomes in the United States over the same period. Rising concentration of income might mechanically increase concentration of giving to the extent that people give the same share of their incomes, but incomes are increasingly concentrated in a few top earners. A burgeoning literature quantifies economic inequality in the United States and finds, to varying degrees, an increase in inequality in recent years. ${ }^{3}$

The potential contributions of income shifts to giving are shown in Figure 15.3, which plots the average inflation-adjusted fiscal incomes of top donors over time. ${ }^{4}$ The vertical axis is on a $\log$ scale, which both makes slopes interpretable as exponential growth rates and the large differences between series visible. The top $0.01 \%$ of tax units ranked by giving have very high incomes, consistently over $\$ 1$ million in 2012 dollars over the period and then rising rapidly to over $\$ 8$ million in 2012 .

However, income concentration is unlikely to explain all of the observed concentration of giving among U.S. tax units. We can see this by comparing the $1 \%$ of returns with the highest charitable contributions to those with the highest reported incomes. Figure 15.4 compares the share of charitable contributions made by the top $1 \%$ and $0.01 \%$ of donors to the shares of giving made by the equivalent fractiles by reported income. Shaded areas show the difference in giving shares between each top-fractile group.

Over time, the top earners account for a greater share of overall charitable giving. However, there is a substantial amount of donor concentration above and beyond what is visible in the rising giving share of the top earners. In 1960, the giving share of top earners was very close to 


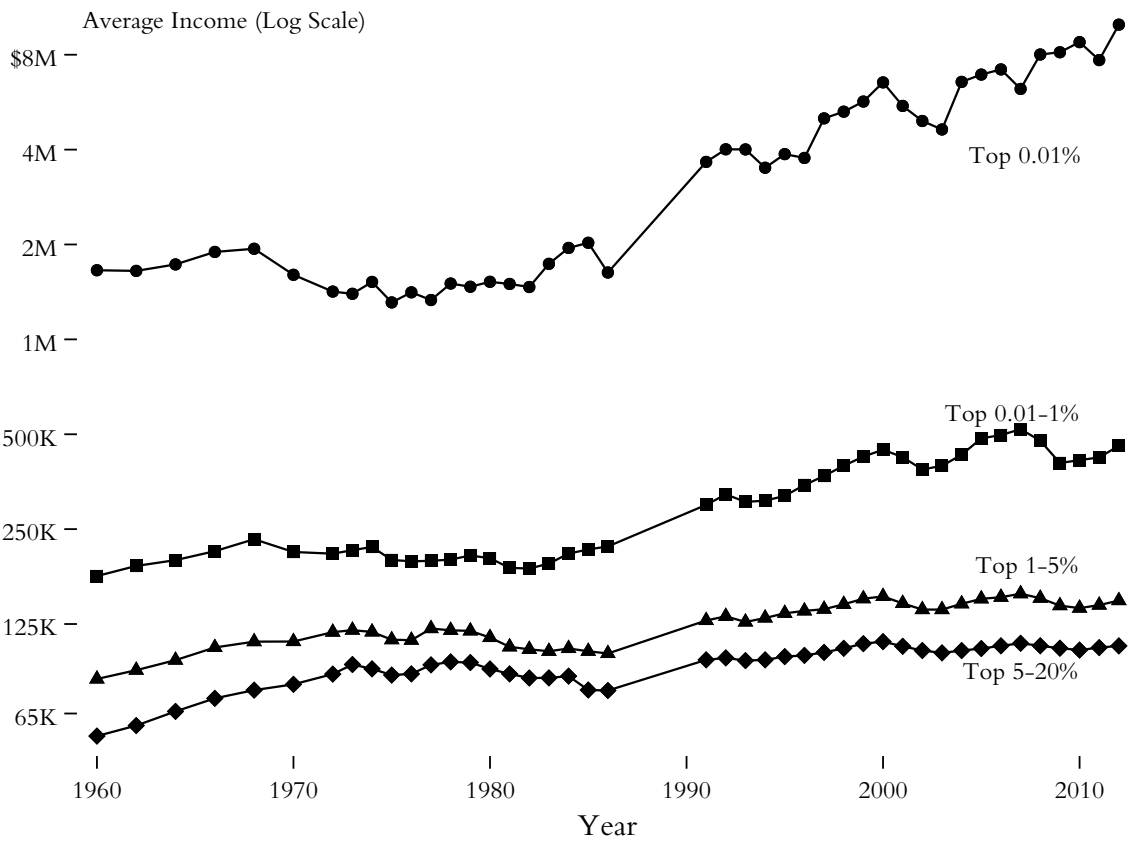

Figure 15.3 Incomes of top donors

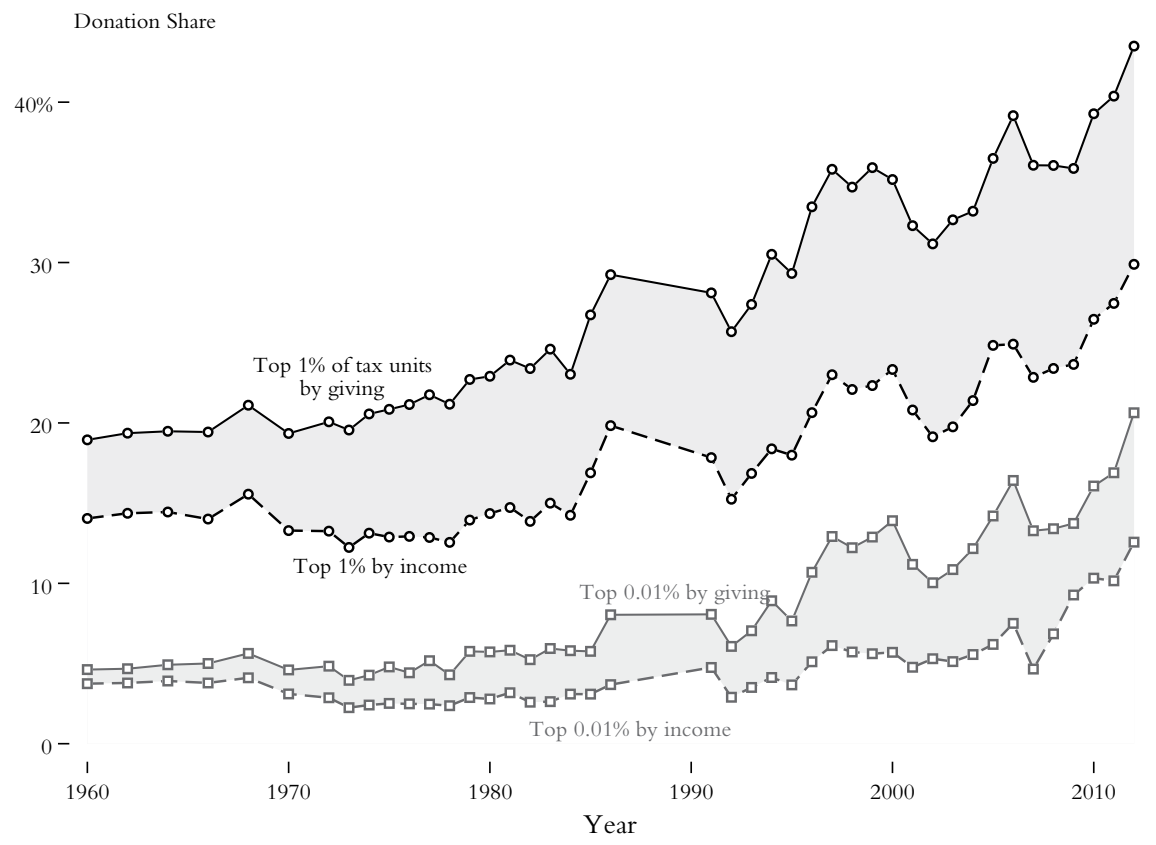

Figure 15.4 Top giving shares of top earners vs top donors 
the share of the top givers, but over time, the two groups diverged substantially. The top $0.01 \%$ of givers provided $4.6 \%$ of giving in 1960 , whereas the top $0.01 \%$ of earners were responsible for $3.7 \%$, a gap of about one percentage point. By 2012, when the top $0.01 \%$ of givers were responsible for $20.6 \%$ of giving, the top $0.01 \%$ of earners gave $12.6 \%$, a gap of 8.0 percentage points. The growth of the gap between the top $1 \%$ of earners and donors is less striking, but it is still substantial, going from about 5 percentage points in 1960 to about 14 percentage points in 2012.

This may be expected simply because the concentration of giving has risen more quickly than even the most extreme estimates of changes in income inequality. The Piketty and Saez (2003) estimates of changes in fiscal income report a steep rise in income concentration of the top $1 \%$ from $8.4 \%$ in 1960 to $18.9 \%$ in 2012, but this increase is not as large as the increase in giving. Moreover, Piketty and Saez's use of fiscal income from tax units likely overstates the degree of income concentration over this period; other inequality research that accounts for mechanical changes in inequality caused by the relationship between tax units and changing marital norms, as well as broader definitions of income not including those not reported on Form 1040, show much less dramatic increases. ${ }^{5}$ While top income groups are giving a greater share of all individual contributions than before thanks to their higher income shares, this alone does not fully explain the rising concentration of giving.

As a final investigation into the relationship between income inequality and donor concentration, we examine the concentration within consistently defined high-income groups. If giving had become more concentrated solely because of changes in the distribution of income, then the concentration of giving within a set of similar tax units should not rise over time. We compute the concentration of giving within consistently defined high-income tax returns over the period 1960-2012. To do so, we restrict each year's data set to tax returns that are married filing jointly and within 20\% of a target income level after adjusting for inflation to year-2012 dollars using the Consumer Price Index. We then compute the share of itemized contributions made by the top $1 \%$ of donors within each group each year. The income targets presented are real incomes of $\$ 1$ million, $\$ 2$ million, and $\$ 5$ million. The top donor shares within these highincome groups are presented in Figure 15.5.

The year-to-year differences in the top donor shares within these groups are noisy, but the trend over time is unmistakably upward. Within each of the three high-income groups, the top $1 \%$ of donors are responsible for roughly $10 \%$ of giving through the 1960 s, rising to shares between $20 \%$ and $40 \%$ of giving in the 2000 s. A simple pooled regression of these top $1 \%$ shares on a trend variable estimates that the top $1 \%$ share within high-income groups has increased about 0.42 percentage points per year over this period; this estimate is statistically different from zero at the $5 \%$ level after correcting for serial correlation.

With the concentration of U.S. charitable giving rising sharply not only nationwide but within groups of similar incomes, other factors than the distribution of resources must be contributing to the long-run trend.

\subsection{Demographic shifts affecting giving}

Other trends have shaped the nature of giving beyond the distribution of resources. The demography of the United States has changed greatly since 1960, as families have grown smaller, the population has become older and more diverse, and gender and marital norms have shifted.

We consider the demographic information inferable from tax returns in Table 15.1. This reports the share of returns that report legal marriage status, that claim dependent children, and that report social security income (which proxies for being retirement age). We present shares for 


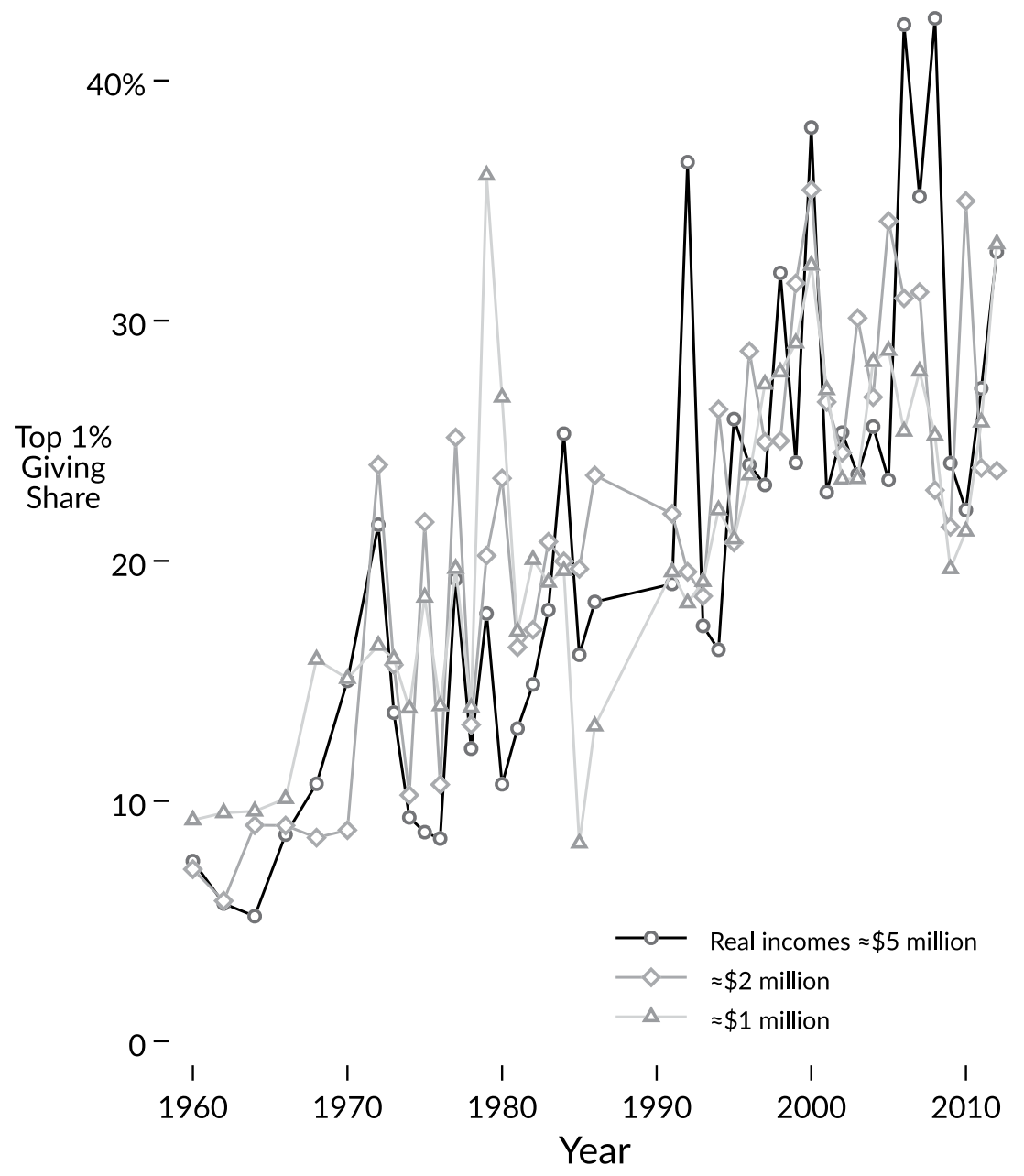

Figure 15.5 Top 1\% donor share within high-income groups

1960 (the first year of tax return microdata), 1970 (the first year of data on children), 1984 (the first year of Social Security reporting), 1995, and 2012 (the last data year). For each variable and year, we report shares for "Top Givers," or those with itemized contributions in the top $1 \%$ of giving for all tax units, and "Other Filers," or tax filers not among the top givers (regardless of whether they itemized or took the standard deduction but excluding nonfilers). The final column presents the difference in percentage points between the first observed year and 2012, and the row below each variable group reports differences between top givers and other filers within each year.

It is clear that top givers and other filers are not alike and that these demographic differences between top givers and others change over time. All mean differences reported in Table 15.1 are statistically different from zero under a two-sided $t$-test with $p$-value less than $0.1 \%$. The magnitudes of the differences are striking as well.

From 1960 to 2012, top donors' marriage rates are consistently high, declining by just over five percentage points, from about $89 \%$ to about $84 \%$. Other filers' marriage rates are lower, and they drop much faster, from $64 \%$ in 1960 to just 39\% in 2012. To the extent that it is necessary 
Table 15.1 Demographics

\begin{tabular}{|c|c|c|c|c|c|c|}
\hline & \multicolumn{6}{|c|}{ Share of filed 1040 returns } \\
\hline & 1960 & 1970 & 1984 & 1995 & 2012 & Change over span \\
\hline \multicolumn{7}{|l|}{ Is married } \\
\hline Top givers & $88.7 \%$ & $87.9 \%$ & $88.7 \%$ & $84.3 \%$ & $83.5 \%$ & $-5.3 \% \mathrm{pts}$ \\
\hline Other filers & 64.3 & 59.8 & 48.2 & 43.3 & 38.5 & -23.8 \\
\hline Difference & 24.4 & 28.1 & 40.5 & 41.1 & 45.0 & \\
\hline \multicolumn{7}{|l|}{ Have children } \\
\hline Top givers & & 59.3 & 52.7 & 47.1 & 39.6 & -19.7 \\
\hline Other filers & & 42.5 & 37.8 & 35.3 & 32.8 & -9.7 \\
\hline Difference & & 16.8 & 14.9 & 11.9 & 6.8 & \\
\hline \multicolumn{7}{|c|}{ Have Social Security income } \\
\hline Top givers & & & 17.9 & 22.9 & 30.2 & +12.3 \\
\hline Other filers & & & 7.2 & 8.6 & 18.1 & +10.9 \\
\hline Difference & & & 10.7 & 14.3 & 12.1 & \\
\hline
\end{tabular}

Sources: Tax return micro data from Internal Revenue Service (2018); total tax units by year taken from the updated data files of Piketty and Saez (2003)

Notes: All variables are weighted by sampling weight. Reported mean differences within groups over time and within time across groups are all different from zero, with $p$-value $<0.001$. "Top givers" are the $1 \%$ of tax units making the largest itemized charitable contributions. "Other filers" are all filed tax returns excluding the top givers. "Is married" is the percentage of each sample with a married filing status (joint or separate). "Have children" is the share of returns with children. "Have Social Security income" is the share of returns reporting social security income.

for most people willing to make large gifts to first feel economically and personally established, this differential in marriage rates may explain the greater share of the top givers, because the "long tail" of middle-income donors may have dwindled over time. ${ }^{6}$

Other differences between top givers and the general population are less dramatic than the differential marriage trends. The shares of both top givers and other filers with children decline over time, although top givers are consistently more likely to have children, with a larger decline over the period 1970-2012, narrowing the gap between these groups. Top givers are more likely to have a retirement-age person in the home than other filers in all years, with the share of both groups reporting social security income growing by about 10 percentage points over the observation period.

Although tax returns provide only limited data about donor demography, the evidence suggests that changes in marriage patterns are likely related to changes in the distribution of giving. In recent decades, American households have seen a bifurcation of household finances: lower-income people have married less and divorced more, whereas high-income households have become more likely to be two-income, dual-professional households who may give differently than a breadwinnerhomemaker pair (Putnam 2000, 2016; Einolf et al. 2018). These speculations cannot be confirmed by tax return data alone, but the demographic information available suggests substantial changes in the distribution of marriage that are strongly correlated with giving behavior.

\subsection{Giving according to charities' reported receipts}

We can next examine whether the lopsidedness of individual giving is reflected in charities' reported receipts. Figure 15.6 plots the share of public support for 501(c)(3) charities according to the receipts of those that report the most. These shares are computed from publicly available 
- ลั๊

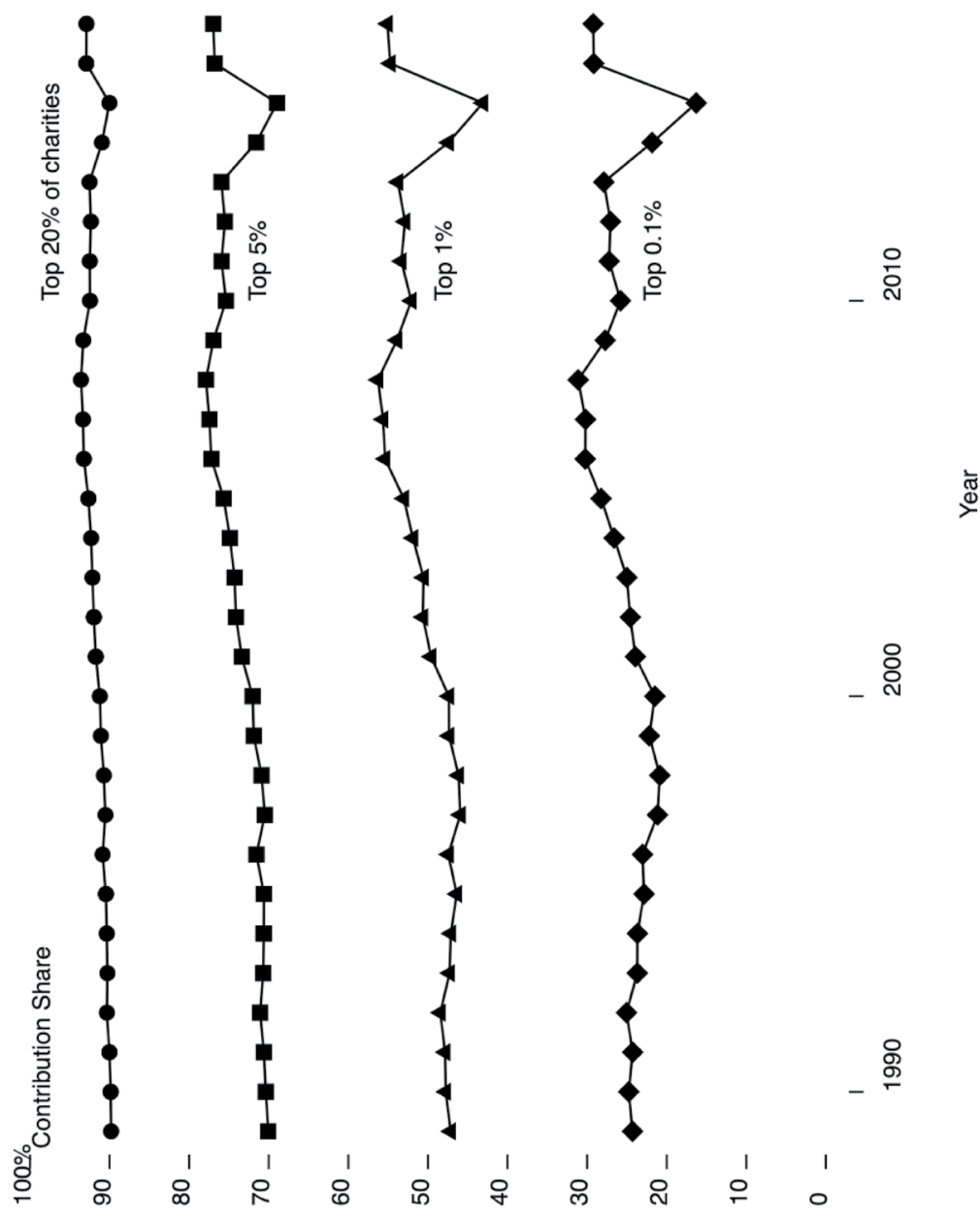

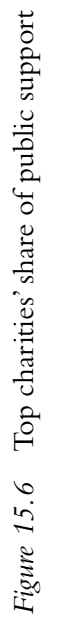


IRS Form 990 data for the years 1989 to 2017, where public support is defined as the sum of contributions, gifts, and grants. Specifically, public support from Form 990 data is rank-ordered and then summed to estimate total public support by top fractile. Unlike individual giving, the figure depicts the share of public support going to the top charities as being fairly flat across the period. The share going to the top 1\% of charities remained below 50\% throughout the $1990 \mathrm{~s}$ before peaking at 56\% around the Great Recession and then falling back down.

This pattern is in stark contrast to the distribution of individual giving, as although public support is fairly concentrated among the top fractiles, it has not become increasingly so. The divergence with the distribution of individual giving is somewhat of a puzzle.

One possible explanation is that the concentration in individual giving in fact reflects the decline in small-dollar donors. These types of donations are disproportionately religious tithes and can be linked to the growing secularization of giving. Figure 15.7 uses Giving USA data to plot real giving per household to religious and non-religious causes from 1967 to 2019. It depicts a steep rise in non-religious giving in the mid-1990s. In particular, real average giving to religious groups has remained fairly stable at around $\$ 1000$ per household, while giving to non-religious organizations has more than doubled, from $\$ 1000$ to $\$ 2500$ per household. While both religious and non-religious giving is recorded in 1040 data, only non-religious organizations are required to file an IRS Form 990 (religious organizations are exempt). ${ }^{7}$ This difference in filing requirements means that any disappearance in small-dollar religious donors would be reflected in individual giving but not 990-filing charities' reported receipts. Of course, this hypothesis can only be tested with donor-level data, but it offers a possible explanation.

Another possible explanation is that the discrepancy is due to the distribution of big gifts across charities over time. Very large gifts from wealthy donors are rare events for the individual

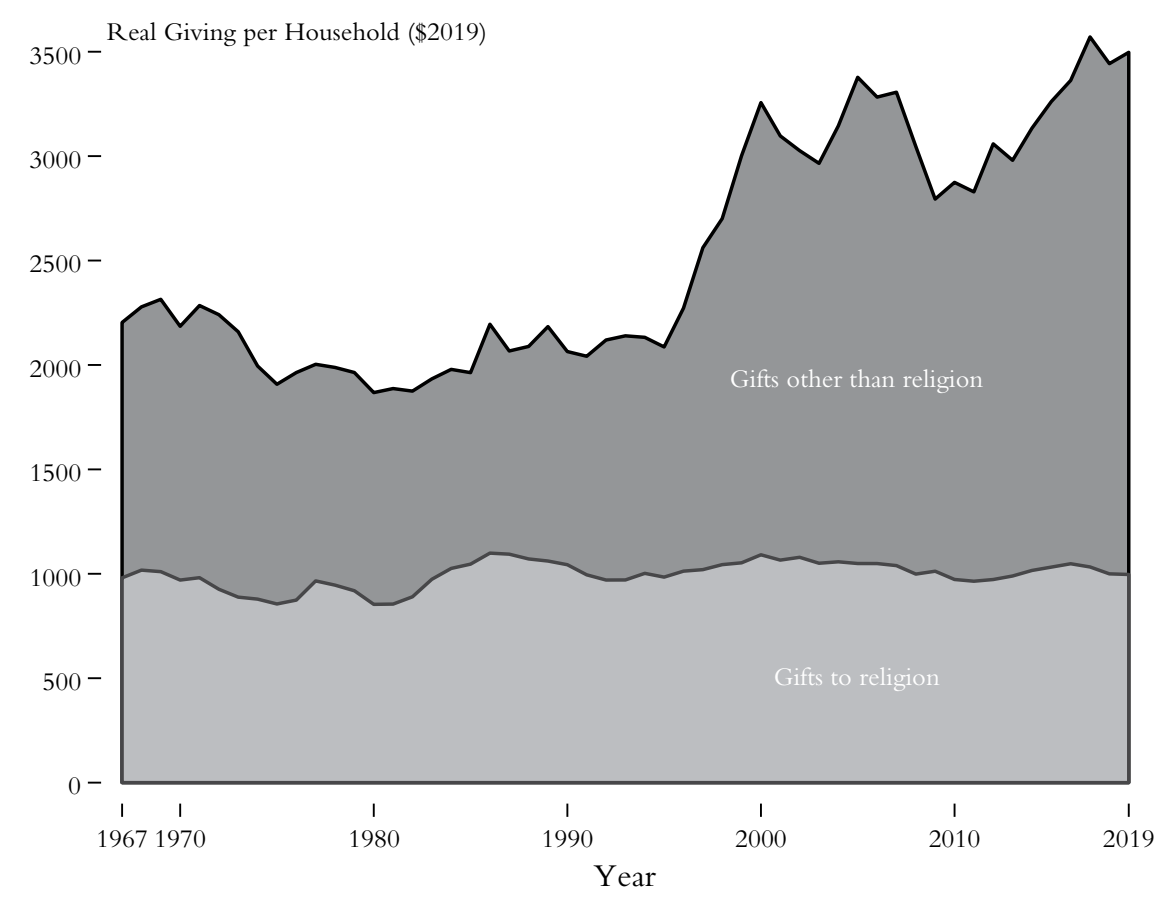

Figure 15.7 Giving USA gifts to religion and others 
but not necessarily for the recipient. For example, one individual's $\$ 1$ million donation to Harvard University would likely represent an outlier relative to that donor's other giving, as well as to other donors, but is not necessarily an outlier for Harvard. In other words, mega-donations are lumpy for the individual but not for the recipient, whose receipts relative to other charities have much lower variance. This means that the increasing number of big gifts would affect the concentration of individual giving but not necessarily the distribution of charities' receipts.

It is further possible that the composition of public support is changing. Form 990 public support, unlike 1040 giving, includes government grantmaking, foundation grants, and transfers from other public charities such as United Way. Figure 15.8 shows that public support and itemized contributions have evolved differently. Prior to 2005, 1040 giving exceeded Form 990 public support; however, that pattern has since reversed, with the latter continuing to rise, while itemized giving has remained fairly flat. This is likely due to the differing composition of 1040 and 990 totals. In particular, 1040 giving includes some components, such as religious giving, that are not included in Form 990 totals. However, given the secularization of giving, as well as the rise in foundation grants (which are not included in 1040 giving), it is unsurprising that Form 990 receipts have overtaken itemized contributions.

We conclude this discussion by looking at the distribution of 990 public support along other dimensions; compared to the dramatic changes in the distribution of Form 1040 contributions among U.S. tax units, Form 990 distributional statistics are remarkably stable.

Figure 15.9 uses Form 990 data to plot the share of public support by sector according to reported receipts for the period 1989 to $2017 .{ }^{8}$ Throughout the period, education remained the sector with the largest share of public support, although this share has steadily declined. Human services remained the second-largest sector and was one of the few to see a rising share of public support during the Great Recession. According to a report by Reich and Wimer (2012), contributions to food banks increased from around $\$ 1.2$ billion in 2007 and 2008 to just under $\$ 1.6$ billion in 2009. Health-related charities form the third largest sector, with public support remaining fairly flat at around $10 \%$ throughout the period. Support for private grantmaking was flat throughout the 1990s and fell during the Great Recession but has climbed in recent years. Arts, culture, and humanities charities have experienced a gradual decline in support since the beginning of the period.

Finally, Figure 15.10 plots the share of public support for charities located in the five largest U.S. cities from 1989 to 2017 . These shares are computed from 990 data, where charity location does not necessary reflect service area. For example, many charities are headquartered in New York City but in fact provide services across the country or world. Nevertheless, the share of public support for New York-based charities declined from around 11\% in 1991 to 6\% in 2014, although this trend has reversed in the most recent years. The remaining cities - Chicago, Los Angeles, Houston, and Phoenix - have maintained a fairly constant share of public support, with Chicago averaging 2.2\% and Los Angeles 1.8\%.

In summary, while U.S. philanthropic giving has become concentrated in a small share of U.S. tax units, 990-filing charities have not seen a similar concentration across charities. Some of this is likely explained by a shift of giving from non-990 charities favored by smaller donors to 990 charities favored by large donors (specifically, the proportional shift of giving from churches to other causes). But much of this also likely reflects a concentration of donors within the average charity, a trend that cannot be observed in the 990 data but which is consistent with the philanthropy trade press's coverage of major-gifts fundraising. For example, the May 2018 issue of the Chronicle of Philanthropy included new and republished articles with titles like "4 Ways to Ask Major Donors for Big Gifts" and "How to Make the Most of Your Meetings with Big Donors." Journal articles have also emphasized the need for special, highly personal strategies 


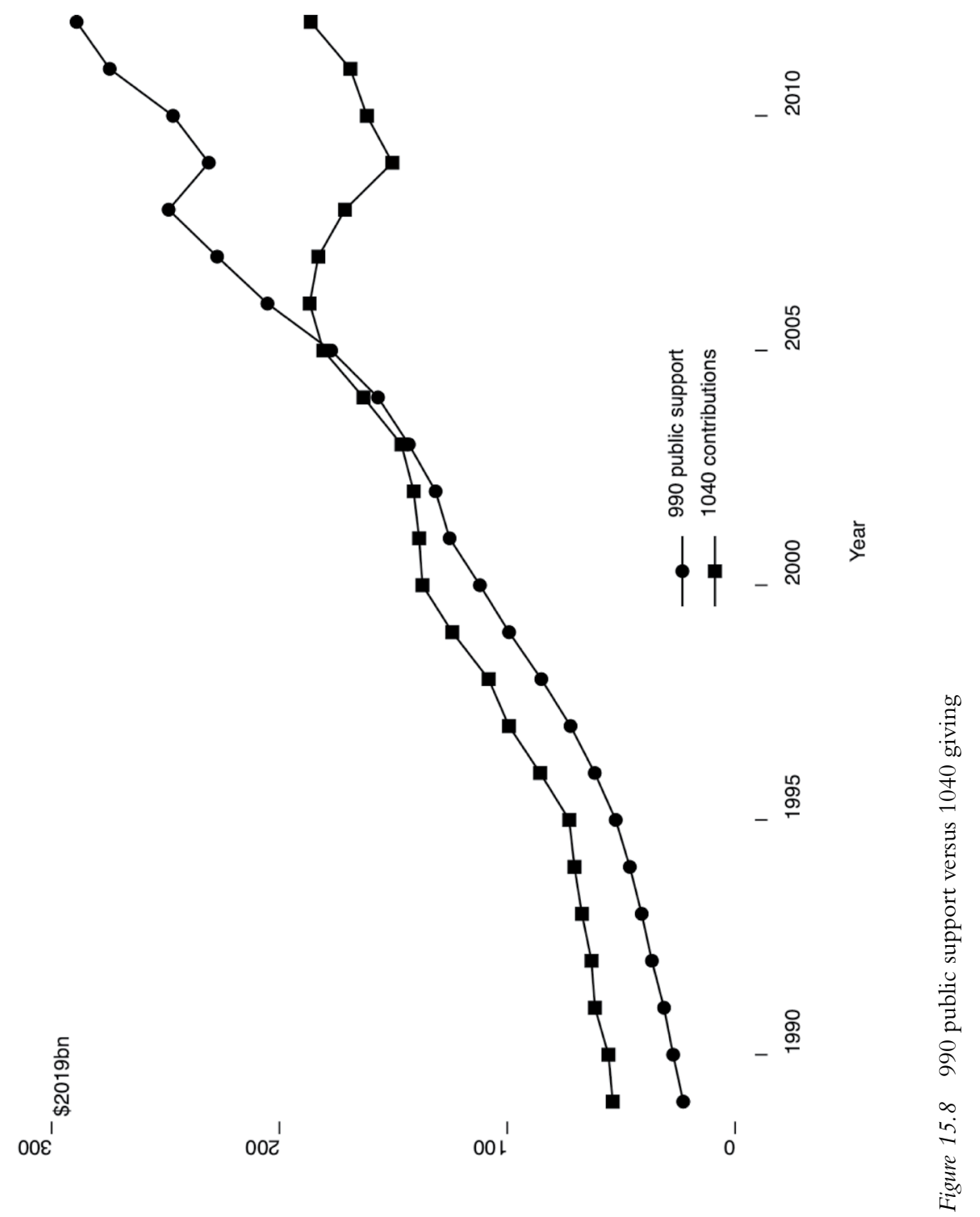


- ฉ̊ำ

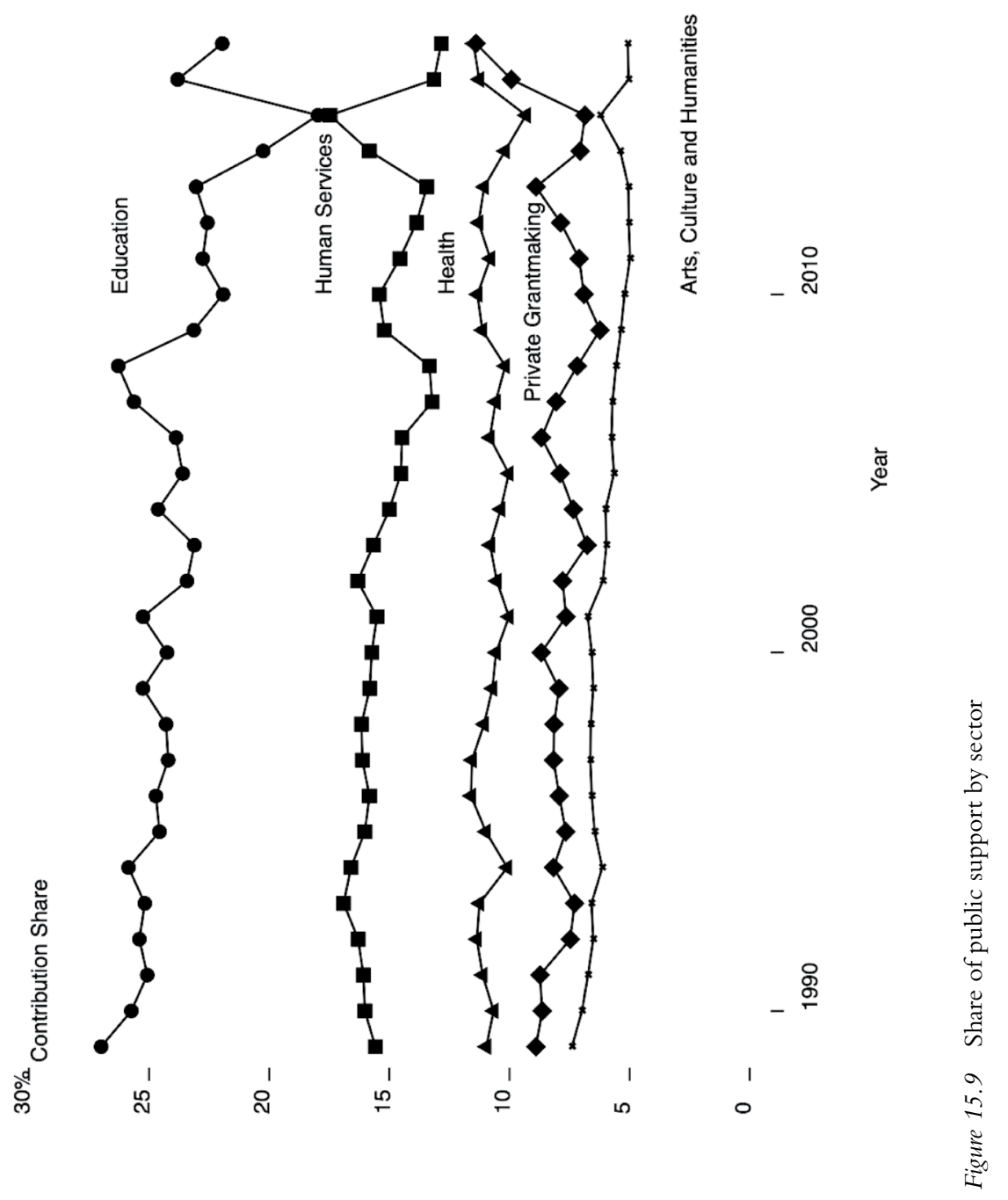




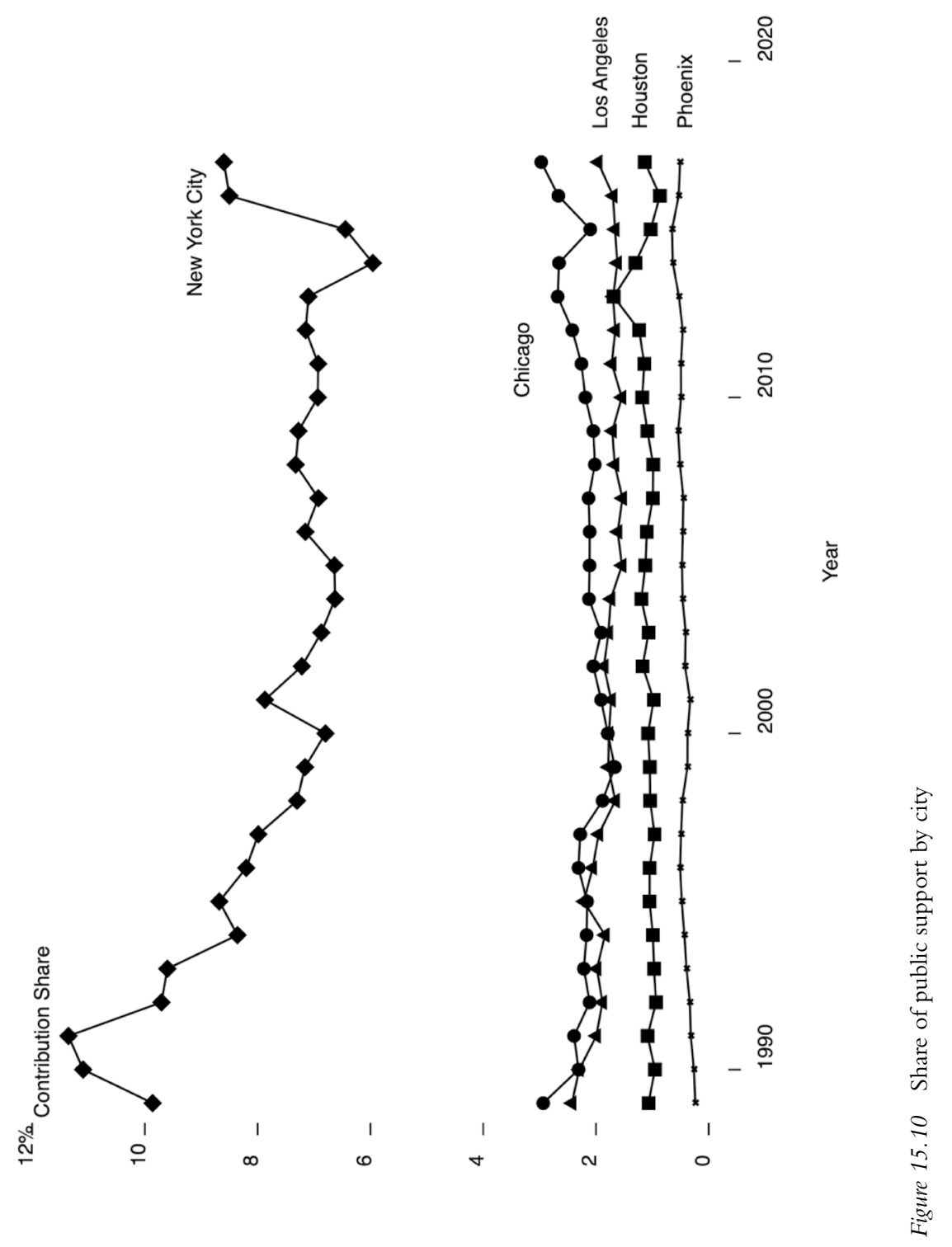


to cultivate large-dollar donors - which is necessarily more labor intensive per donor than mass fundraising (see, for example, Waters 2010; McLoughlin 2017; Drollinger 2018). The upshot: a large number of charities are likely more dependent on a shrinking number of donors to maintain stable public support revenues. In our final section, we consider the role of tax policy in this rising donor concentration.

\section{Tax policy and the distribution of giving}

Tax policy in the United States has a thoroughly studied incentive effect on philanthropy, ${ }^{9}$ but those effects are not uniform across donors or across charities. In many instances, they have actively encouraged the trends described in this chapter or have ineffectively forgone tax revenue to little effect.

\subsection{Tax policy affects the giving distribution}

Tax incentives for philanthropy are especially valuable to high-income, high-wealth households, who deduct against high marginal rates and who are likely to get the most tax savings from the ability to avoid capital gains tax on donation of appreciated assets. ${ }^{10}$ This is a deliberate policy choice; at times when reform of the federal contribution deduction has been considered, policy changes to reduce the deduction's value to wealthy donors (such as the appreciated asset doublebenefit) have often not become law, while those that do benefit these donors (such as increases to the maximum adjusted gross income (AGI) that may be donated) often have (Duquette 2019b). ${ }^{11}$

In recent years, the AGI limitation on giving has increased twice; the 2017 tax reform raised the ceiling on the deductible share of AGI from 50 to $60 \%$ for cash gifts, while the 2020 CARES Act temporarily raised the limit to 100\%. Though few donors give such large shares of their income away, there is a tiny minority of high-wealth households who make up a disproportionate share of contributions, and these tax changes are likely to have an observable effect on their giving decisions (Duquette 2019a) and on the spillovers to rival charities (Mayo, 2021). ${ }^{12}$

Changes in tax policy and the distribution also affect bequests to charity at death. While bequests are largely excluded from taxation at death, tax policy has not always been changed to encourage giving by bequest. The reduction in the top estate tax rate, coupled with the increase in the exemption from $\$ 600,000$ in 1997 to $\$ 11.8$ million in 2020 , has reduced the appeal of tax-motivated charitable bequests by wealthy households. Notably, incentives for "giving while living" strictly dominate the bequest deduction from the estate tax itself, since money given away while alive is also no longer part of a future taxable estate (Joulfaian 2001).

At the state level, states offer both deductions modeled after the federal deduction, as well as targeted, often extremely generous credits supporting particular charity types. The state deductions appear to have donation elasticities comparable to the federal deduction (Bakija and Heim 2011). It is unclear whether state credits, which are narrowly targeted and often subject to low caps on deductible amounts, have a similar effect (Feldman and Hines 2003; Teles 2016; Duquette et al. 2018; Hungerman and Ottoni-Wilhelm 2018).

\subsection{Policy changes to broaden giving}

We recommend three policy changes to bolster policy effectiveness of tax subsidies for charitable contributions. These would expand the pool of potential donors, increase dollars given, and 
increase confidence in the nonprofit sector while controlling the cost of charitable contribution tax expenditures.

First, the federal itemized deduction could be replaced with a nonrefundable credit with a subsidy rate tied to the share of adjusted gross income donated, not marginal tax rate. Such a policy could expand tax subsidies for giving to all households with income tax liability (not just itemizers) and substantially increase total donations with little or no cost to tax expenditures (Duquette 2020). The 2020 CARES Act created a time-limited deduction for non-itemizers' cash donations up to $\$ 300,{ }^{13}$ but this incentive is unlikely to have a large effect on giving relative to its tax cost; as this chapter has shown, giving is highly skewed, and donors who give more than $\$ 300$ /year will have no marginal tax incentive to give more. An incentive with a floor or tiered rate to encourage last-dollar instead of first-dollar giving would be more efficient.

Second, we call for an overhaul of regulations governing the reporting of charitable contributions. The current compliance and reporting regime is open to manipulation and low-scale tax evasion. For example, the $\$ 500$ allowance for deduction of noncash gifts without documentation is widely abused (Tazhitdinova 2018). The United States should require non-public lists of donations linked to tax identifiers from charities, mandate information reporting of donor identities and in- and outflows from donor-advised funds, and expand the required filing of the Form 990 or similar to all organizations allowed to receive deductible contributions.

Third, we argue that charitable contributions for a given tax year should be allowed until the mid-April filing deadline for personal income tax returns in the following year, as is currently allowed for contributions to an individual retirement account. This would improve the effectiveness of the existing incentives in two ways: first, the time horizon for tax savings from charitable giving would be shortened from months to weeks or less and for many donors would be near immediate. ${ }^{14}$ Second, such a policy would allow prospective donors to calculate their marginal tax rates before deciding how much to give. Relative to existing policy, these changes would give tax-motivated donors higher certainty and a timelier incentive without having to increase the generosity of tax expenditures per dollar given. This information would be especially valuable to middle-tier donors who in December would be unsure about whether they will be claiming the itemized deduction (and so have a tax incentive to donate) or the standard deduction (and so have no tax benefit for a modest contribution).

All of these reforms would have the potential to broaden access to tax incentives for giving, improve their effectiveness, and streamline their use. A two-tier tax credit instead of an itemized deduction would expand access to preferential tax treatment and link subsidy rates to the share of income given, not tax bracket. Better information reporting would increase confidence in charities and decrease scope for tax evasion. And a mid-April deadline would let middleincome donors have important information about their tax status before deciding whether and how much to give.

\section{Notes}

1 "Tax units" are a slightly cumbersome demographic unit corresponding to tax returns and returnequivalents who do not file. There are fewer tax units than people but more tax units than households (since cohabiting adults filing separately are one household but more than one tax unit).

2 Series taken from Duquette (2021), which explains the calculation of giving share ratios in detail. In brief, itemized contributions from tax return data are rank-ordered and then summed to estimate total giving by top-giving fractile (Internal Revenue Service 2018). The denominator is taken from Giving USA estimates of total individual charitable contributions (Lilly Family School of Philanthropy, Indiana University/IUPUI 2020). Some years within the 1960-2012 range are not calculated due to 
data limitations or availability, and years after 2012 are not calculated because of the long lag in IRS distribution of new microdata.

3 Some of these estimates of income distribution statistics find very steep increases in U.S. income inequality since the middle 20th century (Piketty et al. 2018; Piketty and Saez 2003). Other methods find a substantially more modest increase, for example, Auten and Splinter (2019).

4 Since these calculations are made using Form 1040 data, income is measured and ranked using the Piketty and Saez (2003) measure of "fiscal income," which is observed in tax returns over time but which omits important income sources that are not reported (such as retained corporate profits) or observed inconsistently (such as Social Security income) or endogenously (such as realized capital gains).

5 See discussions in Auten and Splinter (2019) and Piketty et al. (2018).

6 Additionally, the large differential in trends in marriage rates means that the increasing share of contributions accounted for by the top donors is likely overestimated for mechanical reasons. Because top donor shares are computed as a share of tax units, and because a married couple represents one tax unit whereas an unmarried couple represents two, falling marriage rates among other filers will increase the number of tax units whose giving is summed to compute the top donor share relative to a world where marriage rates were constant across time and groups (see discussion in Auten and Splinter 2019). In the context of giving, average gifts within top donor tiers, which will be biased downward for the same mechanical reason, nevertheless show a dramatic rise over this period, suggesting that mechanical differences from changes in the composition of tax units are secondary to this broader trend (see Duquette 2021, Figure 3).

7 Organizations file the 990 if they are 501 (c) 3 public charities with at least $\$ 50,000$ in revenue and are not churches or other houses of worship. Organizations eligible to receive tax-deductible contributions that do not file a Form 990 include private foundations (which file the Form 990-PF), low-revenue organizations, churches and other houses of worship, and governmental organizations such as public universities. Religiously affiliated charities that are not primarily religious, such as Catholic universities, do file the Form 990.

8 Sector is defined according to the National Taxonomy of Exempt Entities classification system. For a full list, see https://nccs.urban.org/publication/irs-activity-codes.

9 See OECD (2020) for a description of the tax treatment of giving across OECD countries.

10 For a broader discussion on the tax incentives for giving, see Steinberg (2021) and Lideikyte Huber et al. (2021).

11 When appreciated assets are given to qualifying organizations, donors can deduct the fair market value of the asset without first recognizing their capital gains for tax purposes, avoiding the income taxes on both the gains and on the market value's worth of income. Because of this double benefit for giving appreciated assets, there have been periods in American history when it was theoretically possible for very high-income households to wind up with more money by donating highly appreciated assets than liquidating the asset and consuming the after-tax proceeds (Duquette 2019a).

12 These increases may also change reported giving to the extent that giving in excess of the threshold may not be reported by donors on tax returns. Over the 1960-2012 period reported in most of the figures in this chapter, the AGI limitation was increased twice, in 1964 and 1969. Data for years 19871990 are not reported because the IRS public use data censors giving at the AGI limitation, creating a significant downward bias.

13 Internal Revenue Service, November 2020, "Special $\$ 300$ tax deduction helps most people give to charity this year - even if they don't itemize." Press release. https://www.irs.gov/newsroom/ special-300-tax-deduction-helps-most-people-give-to-charity-this-year-even-if-they-dont-itemize

14 Hickey et al. (2019) find that moving the timing of reporting of gifts closer to the timing of giving increases average donations by 9 percentage points.

\section{References}

Auten, G. E. and Splinter, D. (2019). Income inequality in the United States: Using tax data to measure long-term trends. Mimeo. http://davidsplinter.com/AutenSplinter-Tax_Data_and_Inequality.pdf.

Bakija, J. and Heim, B. (2011). How does charitable giving respond to incentives and income? New estimates from panel data. National Tax Journal, 64(2):615-650. 
Drollinger, T. (2018). Using active empathetic listening to build relationships with major-gift donors. Journal of Nonprofit \& Public Sector Marketing, 30(1):37-51.

Duquette, N. J. (2019a). Founders' fortunes and philanthropy: A history of the US charitable contribution deduction. Business History Review, 93(3):553-584.

Duquette, N. J. (2019b). Do share-of-income limits on tax-deductibility of charitable contributions matter for charitable giving? Economics Letters, 174:1-4.

Duquette, N. J. (2021). The evolving distribution of giving in the United States. Nonprofit and Voluntary Sector Quarterly, 50(5):1102-1116.

Duquette, N. J. (2020). A two-tiered charitable contribution credit for all American taxpayers. Nonprofit Policy Forum, 11(4), December.

Duquette, N. J., Graddy-Reed, A. and Phillips, M. D. (2018). The extent and efficacy of state charitable contribution income tax credits. Mimeo. http://www.nicolasduquette.com/research.html.

Einolf, C. J., Curran, H. D. and Brown, K. C. (2018). How married couples make charitable giving decisions. Nonprofit and Voluntary Sector Quarterly, 47(3):657-669.

Feldman, N. E. and Hines, Jr., J. R. (2003). Tax credits and charitable contributions in Michigan. University of Michigan, Office of Tax Policy Research Working Paper Series, no. 2007-3. Ann Arbor: University of Michigan.

Hickey, R., Minaker, B. and Payne, A. A. (2019). The sensitivity of charitable giving to the timing and salience of tax credits. National Tax Journal, 72(1):79-110.

Hungerman, D. M. and Ottoni-Wilhelm, M. (2018). Impure impact giving: Theory and evidence. Working Paper 24940. Washington, DC: National Bureau of Economic Research.

Internal Revenue Service (2018). Individual public use tax file. Statistics of Income Division, Data File. Years 1960-2012. Washington, DC: National Bureau of Economic Research.

Joulfaian, D. (2001). Charitable giving in life and at death. In Gale, W. G., James R. Hines, Jr., and Slemrod, J., editors, Rethinking estate and gift taxation, chapter 8, pages 350-369. Washington, DC: The Brookings Institution.

Lideikyte Huber, G., Peter, H. and Pittavino, M. (2021). Efficiency of tax incentives for charitable giving: Evidence from Switzerland. In Lideikyte Huber, G. and Peter, H., editors, The Routledge handbook of taxation and philanthropy, chapter C. London: Routledge.

Lilly Family School of Philanthropy, Indiana University/IUPUI (2020). Giving USA 2020: The Annual report on philanthropy for the year 2019. New York: Giving USA Foundation.

Mayo, J. (2021). How do big gifts affect rival charities and their donors. Journal of Economic Behavior and Organization, 191: 575-597.

McLoughlin, J. (2017). Advantage, meaning, and pleasure: Reframing the interaction between majorgift fundraisers and philanthropists. International Journal of Nonprofit and Voluntary Sector Marketing, 22(4):e1600.

OECD (2020). Taxation and philanthropy. OECD Tax Policy Studies, No. 27. Paris: OECD Publishing.

Piketty, T. and Saez, E. (2003). Income inequality in the United States, 1913-1998. Quarterly Journal of Economics, 118(1):1-41.

Piketty, T., Saez, E. and Zucman, G. (2018). Distributional national accounts: Methods and estimates for the United States. Quarterly Journal of Economics, 133(2):553-609.

Putnam, R. D. (2000). Bowling alone: The collapse and revival of American community. New York: Simon \& Schuster.

Putnam, R. D. (2016). Our kids: The American dream in crisis. New York: Simon and Schuster.

Reich, R. and Wimer, C. (2012). Charitable giving and the great recession. Nonprofit Management \& Leadership, 13(4):383-399.

Steinberg, R. (2021). The design of tax incentives for giving. In Lideikyte Huber, G. and Peter, H., editors, The Routledge Handbook of Taxation and Philanthropy, chapter C. London: Routledge.

Tazhitdinova, A. (2018). Reducing evasion through self-reporting: Evidence from charitable contributions. Journal of Public Economics, 165:31-47.

Teles, D. (2016). Do tax credits increase charitable giving? Evidence from Arizona and Iowa. Tulane Economics Working Paper 1606. http://repec.tulane.edu/RePEc/pdf/tul1606.pdf.

Waters, R. D. (2010). Increasing fundraising efficiency through evaluation: Applying communication theory to the nonprofit organization - donor relationship. Nonprofit and Voluntary Sector Quarterly, 40(3):458-475. 